\title{
Light and Scanning Electron Microscopic Studies of Trypanosomes Parasites Infecting Freshwater Fishes in Qena Governorate, Egypt
}

\author{
Hussein A. N. A. ${ }^{1 \& 2}$; Rabie S. A. ${ }^{1 \& 3}$; Mohammed N. E. ${ }^{1}$ and Hussein N. M. ${ }^{1}$ \\ 1- Zoology Department, Faculty of Science, South Valley University. Qena, Egypt \\ 2-Biology Department, Faculty of Science, King Khalid University. Abha, Kingdom \\ of Saudi Arabia \\ 3- Faculty of Applied Sciences, Umm Al-Qura University, Saudi Arabia
}

\begin{abstract}
Freshwater fishes were sampled from different localities in the River Nile at Qena Governorate (Qus, Qift, Dandara, El-Trammsa, El-Maana, Dishna and NagHammady). Investigation revealed that Trypanosoma were found parasitized blood of many fish species. Out of 581 blood smears examined, 143 revealed trypanosomes infection with a prevalence of $24.6 \%$. The infected fishes are belonging to seven species and four families. Trypanosomes parasites were found belonged to three species with different infection rates: T. mukasai Van As et al. 2004 (28.3\%); T. cyanophilum Mohamed, 1978 (52.9\%) and T. cataractae Putz, 1972 (1.5\%). A new Trypanosoma species was found infecting Ch. ruppelli fish with an infection rate of $1.96 \%$. Histological sections showed the presence of the adult stage of T. mukasai in between liver cells. Also T. mukasai had been examined using scanning electron microscope.
\end{abstract}

Keywords: Fishes, Freshwater, Trypanosma, Infection rate, Qena, Egypt

\section{INTRODUCTION}

Genus Trypanosoma belongs to haemoflagellates is prevalent in both marine and fresh water fishes; they are living principally extracellularly in the blood and tissue fluids (Hoffman, G.L., 1970; Duijn, C.V., 1973; Al-Salim, N.K., 1980 and Overath, et al., 1999).

Most species of trypanosomes in the natural hosts produce no serious damage, however; several species cause pathogenic diseases of considerable medical and economic importance. This is particularly true in the tsetse fly areas of Africa, where sleeping sickness of man and trypanosomiasis in cattle, sheep, horses and goats are amongst the major obstacles to economic and social progress.

In Europe, Laveran, A. and Mesnil, F. (1901) described two forms of Trypanosoma remake from the pike Esox lucius in France, Keysselitz, G. (1906) found the same parasite in the same host fish in Germany and England respectively, Hawking, F. (1957) found Trypanosomes in the English fresh water perch. Qadri, S.S. (1962) described T. winchesiense in the blood of the mirror carps. Prevalence of T. granulosum consistently high in eels from the lake sites in western Ireland (Zintl, et al., 1997). Akmirza, A. and Tepecik, R.E. (2007) had been studied the seasonal variation in some haematological parameters in naturally infected and uninfected roach (Rutilus rutilus) with Cryptobia tincae in Marmara region, Turkey.

Minchin, E.A. (1909) described the polymorphic trypanosome (T. percae) from the English percea var. Canadensis from Canada. The hemoflagellate $T$. catostomi was described by Daly, J.J. and Degiusti, D.L. (1971) from the blood of white sucker (Catostomus commersoni) from Flemings Creek in Washtenaw country, Michigan, T. catostomi was 
described in 33 of 285 white suckers (prevalence $11.6 \%$ ) (Lom, G., 1979 and Woo, P.T.K., 1987 and 1994). T. carassii is a wide spread parasite of carp and other cyprinid as well as some noncyprinid fresh water fish in West Virginia, USA (Lom, J. and Dykova, I., 1992). T. immanis has been found parasitizing Loricariichthys anus from Rio Grande do Sul, Brazil (Froes, et al., 1978).

In Asia, China, T. clariae had been recorded -for the first time- from $C$. macrocephallus by Mantel, R. (1905). The research concerning trypanosomes in fishes had many steps. Qadri, S.S. (1955) described T. striate from Ophicephalus striatus in Hydarabad, India. Hassan, R. and Qasim, S.Z. (1962) reported T. punctati from Ophiocephalus punctatus in India. Qadri, S.S. (1962) described T. batrachi from the Indian fish C. batrachi. Trypanosomes occur in C. lazera, in the Near East, but not in Cichlids or Cyprinids. Trypanosomes have also been reported from introduced Or. mossambicus in India (Mandal, A.K., 1977).

Regarding to Arabic countries, A few new species of trypanosome has been recorded and described in Iraq (Warsi, A.A. and Fattohy, A.L., 1976; Fattohy, Z.L., 1978; Al-Jafry, A.R. and Rahema, Z.I.F., 1982; Al Salim, N.K., 1985; Al-Jafry, et al., 1988 and Al-Salim, et al., 1990 and 1992).

Prior to 1960 Knowledge of Trypanosomes infecting fresh water fishes in Africa was limited to probably 13 publications describing almost as many species These records were form fishes in French, West Africa, Congo, Sudan, Uganda Mosambique and Natal (Baker, J.R., 1960, 1961). Careful scrutiny of these reports led to conclude that only three of these species could be considered valid: T. toddi Bouet, 1909, T. mukasai Hoare, 1932 and T. tobeyi Dias, 1952. Even so, Baker, J.R. (1960) noted that a "small difference in nuclear position" was the only character separating $T$. toddi from $T$. tobeyi, he also reported that $T$. toddi was not remarkably different from T. mukasai and T. tobeyi might prove asynonym of the same trypanosome.

Since 1961, new species of trypanosomes from fresh-water fishes have been described from South Africa and Egypt (Pienaar, U.D.V., 1962 and Negm- El-Din, M.M., 1997, 1998), and T. froesi Lima, 1976, from the Rivers and lagoons of southern Africa (Paperna, I. 1996 and Smit, et al., 2000). However, elucidation of the life cycle of T. mukasai involving its transmission to a variety of wild-caught host fishes has led to the conclusion (Negm- El-Din, M.M., 1998) that most records of fresh water fish trypanosomes across Africa may be of a single species, (T. mukasai).

Sudan is one of the earliest African countries in which fish trypanosomes had been reported, where trypanosomes recorded by Neave, S. (1906) in the blood of Mugil sp., B. bayad and Synodontis schall; and in blood of Ophicephalus obsccurus, in the mugil sp., B. bayad, S. schall, Ch. auratus, C. anguillaris and Ti. zilli by Wenyon, C.M. (1909). In 1976, Saoud came with some new hosts (Mormyrus kannume, B. bayad, B. docmac, Ch. auratus, C. angullaris, C. lazera, S. schall, S. batensoda, S. membanceus, S. serratus, S. khartomensis, S. filamentosus and Ti. zilli) harboring trypanosomes caught from the Nile River in the Sudan.

In other African countries fish trypanosomes had been found parasitizing C. angolensis in the Congo by Dutton, et al. (1907). Bouet, (1909) described $T$. toddi from $C$. angullaris in French West Africa. He believed that $T$. toddi was the same as that described by Dutton, et al. (1907). Fantham, H.B. (1919) recorded trypanosomes in the blood of C. gariepinus in South Africa. Baker, J.R. (1960) described T. mukasai in five genera of fish in Uganda. He 
concluded that all Trypanosomes of African fresh-water fish could be related to T. toddi Bouet, 1909, T. mukasai Hoare, 1932 and T. tobeyi Dias, 1952. In Lake Victoria, Or. variabilis and Or. esculenta were infected with trypanosomes, Or. niloticus in Lake George (Baker, J.R., 1960 and 1961). From the silver catfish Schilbe intermedius Ruppell, 1832, tentatively identified T. mukasai,in the Okavango Delta region of Botswana (Smit, et al., 2000). T. mukasai from different fishes in the Okavango Delta, Or. andersonii, Serranochromis angusticeps, Se. macrocephalus, Se. robustus, C. gariepinus, $C$. theodorae, Parauchenoglanis ngamensis, $S$. nigromaculatus, $S$. vanderwaali, Sc. intermedius (Smit, et al., 2004). Trypanosoma infection was observed in C. gariepinus, Lagos Nigeria, where the overall prevalence was $7.23 \%$; while the overall prevalence of trypanosome infection in S. Clarias was $35.24 \%$ (Hassan, et al., 2007).

In Egypt, Fresh-water fish's trypanosomes had a little focused. Mohammed, M.A., 1978 had described T. alhaussainii from C. lazera caught from the Nile near Cairo. Marwan, A.M. (1980) described this species in C. lazera and other three species (T. synodonti $\mathrm{n}$. sp. from S. schall, T. bagri n. sp. from $B$. bayad, and T. mansouri Mohammed, 1978 in Ch. auratus) from the River Nile at Assiut, Upper Egypt.

The present study aimed to identify and describe the blood parasites of the genus Trypanosoma parasitizing freshwater fishes in Qena Governorate, Egypt.

\section{MATERIALS AND METHODS}

Freshwater fishes were captured from different localities of the River Nile in Qena Governorate. The collected fishes were identified according to the Publication of National Biodiversity Unit No. 9, 1997. Blood smears from the caudal veins of each fish have been made. Air -dried blood smears were fixed in methanol and stained using Giemsa's stain and then examined for Trypanosomes.

From the infected fish with $T$. mukasai in B. bayad small pieces of liver, spleen and kidney were washed in saline solution $0.7 \%$, fixed in formolalcohol glacial acetic acid, dehydrated in ascending series of ethyl alcohol. The specimens have been cleared in xylene, impregnated in paraplast wax, embedded and sectioned. After removing of wax the sections have hydrated in descending series of ethyl alcohol. The sections have been stained in Ehrlich's hematoxylin stain and differentiated then stained in Eosin stain. After completion dehydration, clarified, mounted in Canada balsam, the sections have examined using light microscope.

The infected blood with T. mukasai in B. bayad has spread on a cover slip, fixed in phosphate buffered 5\% gluteraldehyde (PH 7.4), post-fixed in $1 \%$ osmium tetraoxide. The smears washed in Na-phosphate buffer (PH 7.4) then processed in drying apparatus, subsequently mounted on copper studs and gold coated. The smears had been examined using JEOL JSM-T5 kv scanning electron microscope (SEM).

\section{RESULTS}

Trypanosomes were found parasitized many fish species. Out of 581 examination blood smears, 143 revealed trypanosomes infection with a prevalence of $24.6 \%$. The infected fishes are belonging to four Families: Bagridae ( $B$. bayad, Ch. rueppelli, Ch. auratus); Cichlidae (Ti. zilli, Or. niloticus); Clariidae (C. lazera); Cyprinidae ( $L$. niloticus).

\section{1- T. mukasai Van As et al., 2004 (Figs.} 1-8)

T. mukasai had been found parasitizing blood in different species of fishes (B. bayad, Ch. auratus, $C$. 
gariepinus, Ti. zilli, Or. niloticus and $L$. niloticus). Generally, the infection rate was 29.3\%. Description of these trypanosomes species in each infected host species are:

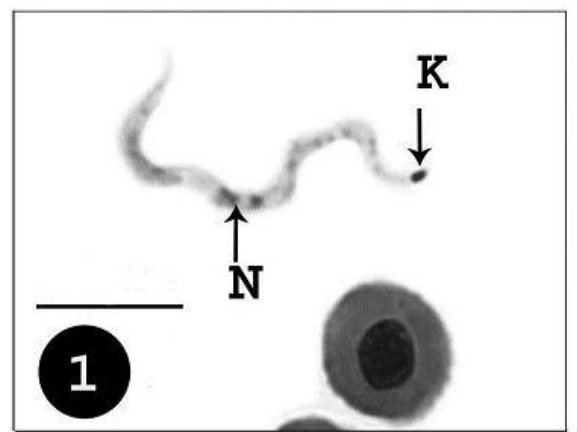

Figs. 1\&2: Photomicrograph of T. mukasai Van As et al. 2004 in B. bayad fish; Fig. 1. Showed an oval kinetoplast, pigments, and an elongate nucleus (S. bar $10 \mu \mathrm{m})$; Fig. 2. Showed a rounded kinetoplast, undulating memberane, free flagellum, and pigments (S. bar $10 \mu \mathrm{m})$.

The body is generally thin, elongated and cylindrical with pointed anterior end while the posterior end is fairly blunt. It measures $32.1-40.7 \mu \mathrm{m}$ in length and the free flagellum length ranged from 16.5 to $17.2 \mu \mathrm{m}$ when present while it couldn't recognized in some samples. It has a distinct undulating membrane. The cytoplasm stained faint blue and includes blue violet granulated bands near the edge opposite to the undulating membrane. The nucleus has an elongated form, oval structure situated in the anterior half of the body. The nucleus lies at the end of the first half or slightly anterior to the middle of the body, it measured 3.0-4.4 and 1.0-2.1 $\mu \mathrm{m}$ in length and width, respectively. The nuclear index (distance between middle of
A- T. mukasai in B. bayad (Figs. 1\&2).

T. mukasai was observed in 92 (86.7\%) out of 106 examined B. bayad fishes. Neither polymorphic nor division stages were seen in the blood smears. One form only has been observed and described.
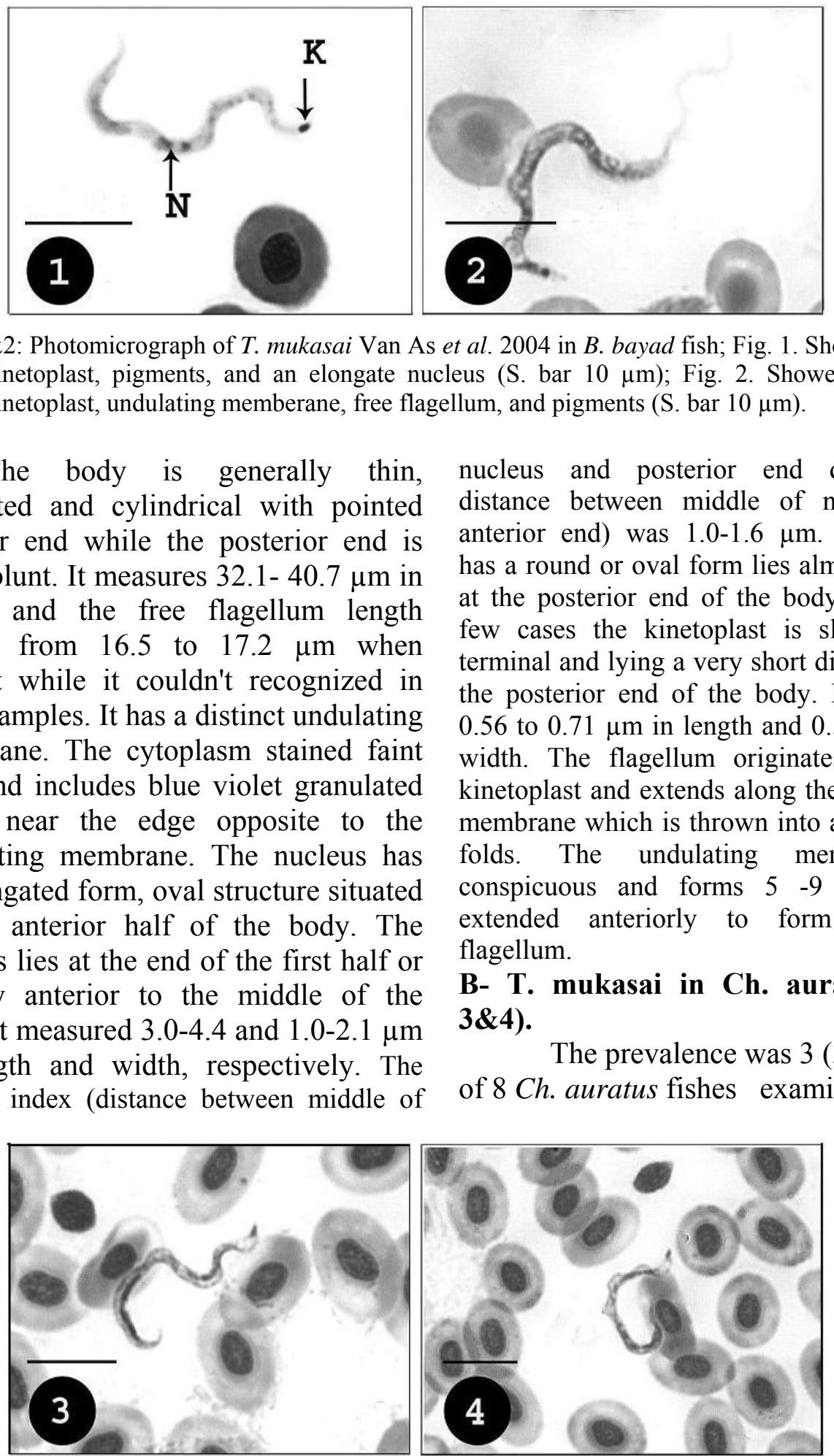

Figs. 3\&4: Photomicrograph of T. mukasai in blood of Ch. auratus (S. bar $10 \mu \mathrm{m}$ ). 
The body is relatively long and cylindrical with pointed anterior and posterior end it is (34.5-35.7) $\mu \mathrm{m}$ in length and the flagellum length ranged from 9.5 to $13.8 \mu \mathrm{m}$. The cytoplasm stained faint violet and showing many staining granules those aggregated to form a marginally located band which is basophilic in reaction and stained deeper than the rest of cytoplasm. The nucleus rounded or oval shaped. It is small in size (1.4-1.8 $\mu \mathrm{m}$ in length and $0.7-1.2 \mu \mathrm{m}$ in width). It lies in the anterior half of the body. The nuclear index was $(1-1.25)$ $\mu \mathrm{m}$. It has a large kinetoplast measured 2.0-3.5 and 1.5-2.3 $\mu \mathrm{m}$ in length and width, respectively. The deeply stained extends to the pointed posterior end of the body. The flagellum arises from the kinetoplast and extends forming undulating membrane which is thrown into $(3-7)$ folds; it is broad in certain parts and narrows in others; free flagellum is generally rather short and not easily stained.

\section{C- T. mukasai in C. lazera (Fig. 5)}

T. mukasai has been observed in $6(21.4$ $\%)$ out of 28 C. lazera fishes investigated.

It has a long body, body length ranged from 38.5 to $41 \mu \mathrm{m}$ in length and the free flagellum ranged from 9 to 11.5 $\mu \mathrm{m}$ length. The body has a rounded or pointed posterior end and tapering anterior end.

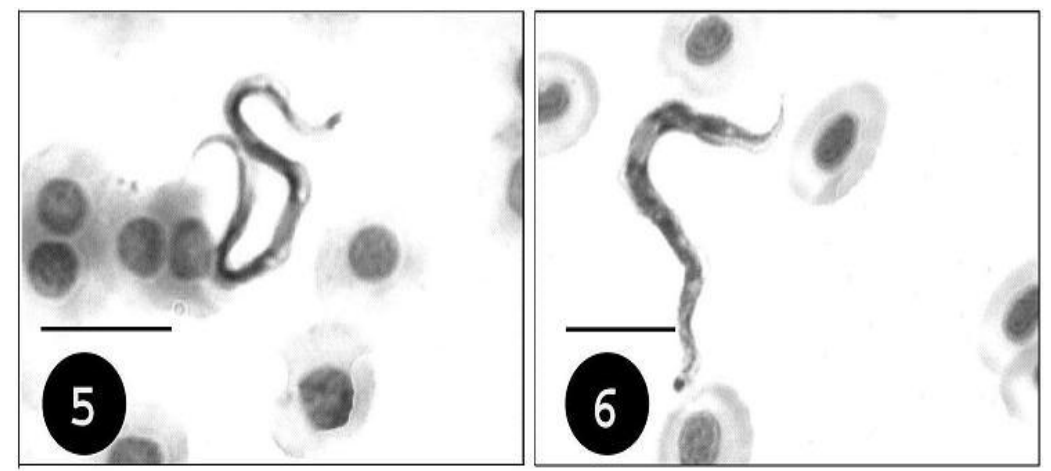

Fig. 5: Photomicrograph of T. mukasai in blood of C. gariepinus (Lazera) showing the elongate nucleus and rounded kinetoplast; Fig. 6. Photomicrograph of T. mukasai in blood of Or. niloticus fish (S. bar $10 \mu \mathrm{m})$. E- T. mukasai in Ti. zilli (Fig. 7)

The cytoplasm stained faint violet and has numerous basophilic deeply stained granules aggregated to form a marginally located band. Also the cytoplasm contains many vacuoles at the posterior part of the body. The nucleus has an oval or slightly elongated shape and lies nearest to the anterior end. It measured 3-4 $\mu \mathrm{m}$ in length and $2.1-$ $2.7 \mu \mathrm{m}$. The nuclear index was $1.3-1.5$ $\mu \mathrm{m}$. Kinetoplast has a rounded or oval shape lying at the posterior end of the body. It measured $1.0-1.8 \mu \mathrm{m}$ in length and $0.5-1.0 \mu \mathrm{m}$ in width. The undulating membrane showed $3-6$ folds.

\section{D - T. mukasai in Or. niloticus (Fig. 6)}

Out of 180 Or. niloticus fishes examined, 8 (4.4\%) fishes were found harboring T. mukasai.

The body is relatively long and cylindrical with pointed anterior end. The body length ranged from 41-43.5 $\mu \mathrm{m}$ and $1.8-2.5 \mu \mathrm{m}$ in width. There was no ability to detect and measure the free part of the flagellum clearly. The violet stained cytoplasm contains numerous staining granules in anterior and posterior parts of the body. It contains an elongated oval nucleus, 2.7-3.2 in length and 1.5-1.8 $\mu \mathrm{m}$ in width. It lies in the anterior half of the body and the nuclear index is 1-1.4 $\mu \mathrm{m}$. 
There is a small and spherical kinetoplast, it is $0.7-0.9 \mu \mathrm{m}$ in length and $0.7-0.9 \mu \mathrm{m}$ in width. It lies at the posterior end of the body and deep violet stained. The undulating membrane thrown into 5-9 folds. The free part flagellum is generally short.

\section{E- T. mukasai in Ti. zilli (Fig. 7).}

This species of trypanosome was observed in $4(6.1 \%)$ out of $66 \mathrm{~T}$. zilli fishes. The elongated body contains an elongate nucleus lies near to the anterior end of the body. Also the body contains many vacuoles and stained granules.

The body is cylindrical, 40.2-42.5 $\mu \mathrm{m}$ in length with pointed anterior end and blunt posterior end. Cytoplasm contains vacuoles and stained granules. The elongated nucleus measures 3.5-4 $\mu \mathrm{m}$ in length and 1.1-1.8 $\mu \mathrm{m}$. It stained violet and lies slightly anterior to the middle of the body. The nuclear index was 1.1-1.3 $\mu \mathrm{m}$. The kinetoplast has terminal position near to the posterior end of the body. It stained blue, oval or round in shape and measured 0.7-0.9 $\mu \mathrm{m}$ in width and $0.7-1.3 \mu \mathrm{m}$ in length. The free part flagellum is generally short.

\section{F- T. mukasai in L. niloticus (Fig. 8)}

Only one $(6.6 \%)$ out of $15 \mathrm{~L}$. niloticus examined was found to be infected with T. mukasai.

The body is relatively long and cylindrical with pointed anterior and posterior ends; (50-53) $\mu \mathrm{m}$ in length, free flagellum length is (11-14) $\mu \mathrm{m}$. The deep violet stained cytoplasm contains many vacuoles in both anterior and posterior parts of the body. The nucleus has spherical to oval in shape.

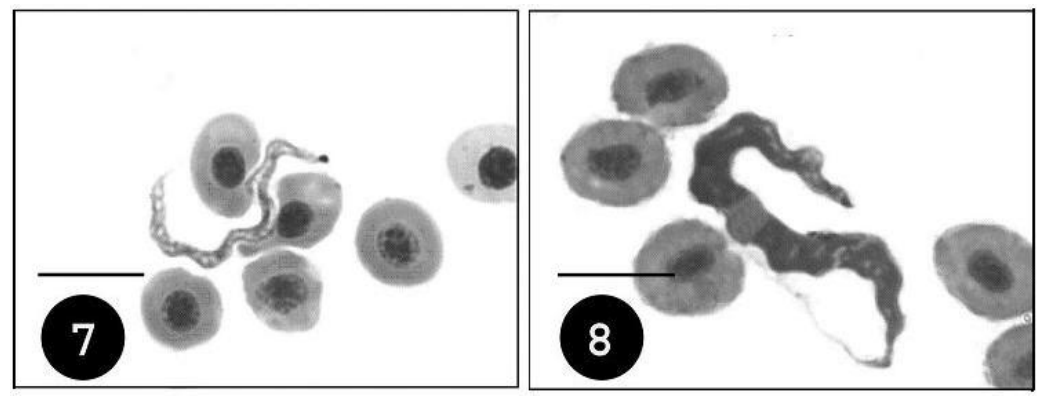

Fig. 7: Photomicrograph of T. mukasai in blood of Ti. zilli (bar $10 \mu \mathrm{m}$ ); Fig. 8. Photomicrograph of T. mukasai in blood of L. niloticus (S. bar $10 \mu \mathrm{m}$ ).

It lies in the posterior half of the body and measured 4-4.3 $\mu \mathrm{m}$ in length 3-4 $\mu \mathrm{m}$ in width. The nuclear index was 1-1.2 $\mu \mathrm{m}$. The elongated kinetoplast measured $1-1.2 \mu \mathrm{m}$ in length and $0.5-0.7 \mu \mathrm{m}$ in width. It has sub-terminal in position closed to the posterior end of the body.

(2)- T. cyanophilum Mohamed, 1978 (Figs. 9-11)

T. cyanophilum were observed in $27(52.9 \%)$ of 51 specimens of $C h$. ruepelli. It is a polymorphic trypanosome species had been found in three forms; small, medium, and the large forms. Small form (Fig. 9).
This form has been detected in the blood of all infected specimens. The thin and elongate body measured 24 $26.7 \mu \mathrm{m}$ in length and $3.2-3.5 \mu \mathrm{m}$ in width. The body has pointed anterior end and slightly rounded posterior end and contains many vacuoles. The free part flagellum length is $7-9 \mu \mathrm{m}$. The cytoplasm contains fine granules and many vacuoles. The oval shaped nucleus measured 2.8-3.2 $\mu \mathrm{m}$ in length and 3.1$3.5 \mu \mathrm{m}$ in width. The nuclear index was 1.3-1.63 $\mu \mathrm{m}$. The rod-like kinetoplast measured 1.3-1.8 $\mu \mathrm{m}$ in length and 0.5$0.7 \mu \mathrm{m}$ in width. It has terminal or slightly sub-terminal position. 


\section{Medium form (Fig. 10)}

This stage has been found in the blood of all infected fish species. The body is longer (37 $\mu \mathrm{m}$ in length) more wide $(4.7 \mu \mathrm{m})$ comparing with the small form. The body has a pointed anterior end. Cytoplasm contains fewer vacuoles. It contains a large nucleus measured 4.8 $\mu \mathrm{m}$ in length and $4.5 \mu \mathrm{m}$ in width. The nuclear index was $1.2 \mu \mathrm{m}$. It contains a terminal or slightly sub-terminal oval shaped kinetoplast. The free part of flagellum has been not easily recognized. The large form (Fig. 11)

The large form of $T$. cyanophilum was rare and observed only in one infected Ch. ruepelli.

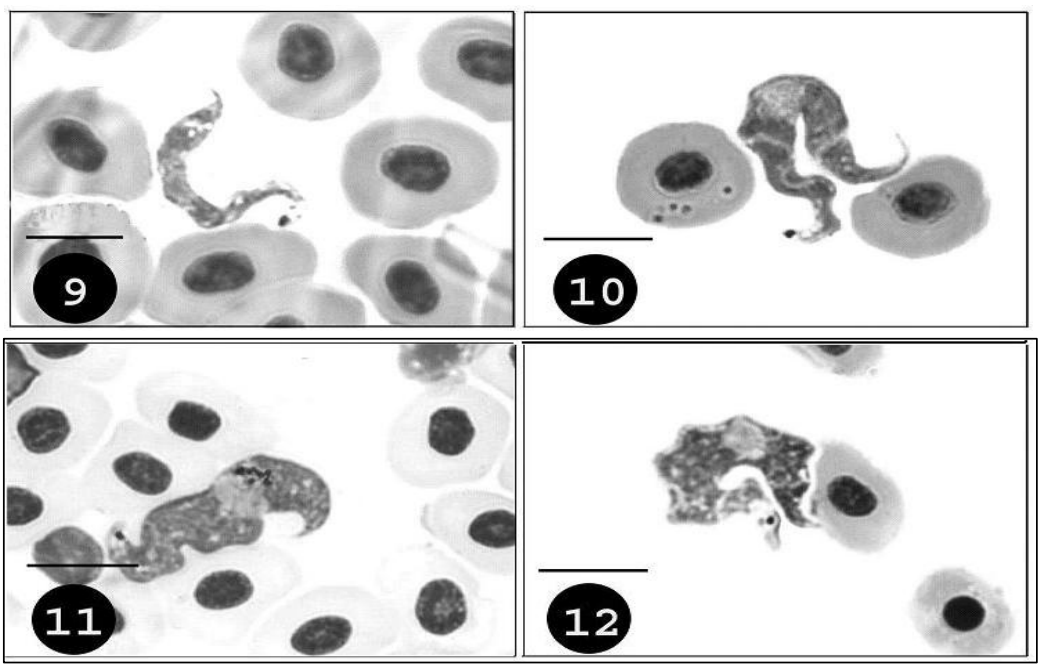

Figs. 9-11: Photomicrograph of T. cyanophilum Mohamed, 1978 in the blood of Chrysichthys rueppelli (S. bar $10 \mu \mathrm{m}$ ); Fig. 9. Small form; Fig. 10. Medium form; Fig. 11. Large form.

Fig. 12: Photomicrograph of T. cataractae Putz, 1972 in the blood of Ti. zilli (S. bar $10 \mu \mathrm{m})$.

The body is large and wide. The body measured $34 \mu \mathrm{m}$ in length and 0.8 $\mu \mathrm{m}$ in width. The free part of the flagellum measured $11.5 \mu \mathrm{m}$. The body has a pointed anterior end and a rounded posterior end. It contains a large size nucleus that measured $6.5 \mu \mathrm{m}$ in length and $5.6 \mu \mathrm{m}$ in width.

There are seven large stained granules in the posterior part of the nucleus and many other small stained granules spread inside the body in addition to many vacuoles. The nuclear index is $1.7 \mu \mathrm{m}$. The kinetoplast was strongly shifted to the posterior tip with a measurement of $1.1 \mu \mathrm{m}$ in length and 0.8 $\mu \mathrm{m}$ in width.

\section{(3)- T. cataractae Putz, 1972 (Figs.}

\section{2\&13).}

One fish only $(1.5 \%)$ out of $66 \mathrm{Ti}$. zilli examined was $T$. cataractae. The body is roughly ovoid or rounded similar to "C" shaped without a flagellum. It measured 17-20 $\mu \mathrm{m}$ in length and 6.5-8.0 $\mu \mathrm{m}$ in width and mostly found adhering to the red blood cells.

\section{(4)- Trypanosoma species (Fig. 14)}

This trypanosome species was observed in one fish only $(1.96 \%)$ out of 51 Ch. ruppelli fish. No polymorphism or division stages were seen in the blood of this specimen. The body is wide and both ends are pointed. It measured $48.5 \mu \mathrm{m}$ in length and $5.5 \mu \mathrm{m}$ in width and the free part of the flagellum couldn't be recognized. There are many stained granules near the body margin and others spread inside the body. The nucleus is oval in shape and measured 4.5 and 3.8 $\mu \mathrm{m}$. The nuclear index is $1.6 \mu \mathrm{m}$. The kinetoplast measured 1.0 and $0.7 \mu \mathrm{m}$. 
Histological sections of T. mukasai Van As et al. 2004 parasitizing liver of $B$. bayad showed the presence of the adult stage of T. mukasai in between liver cells (Figs. 15\&16).
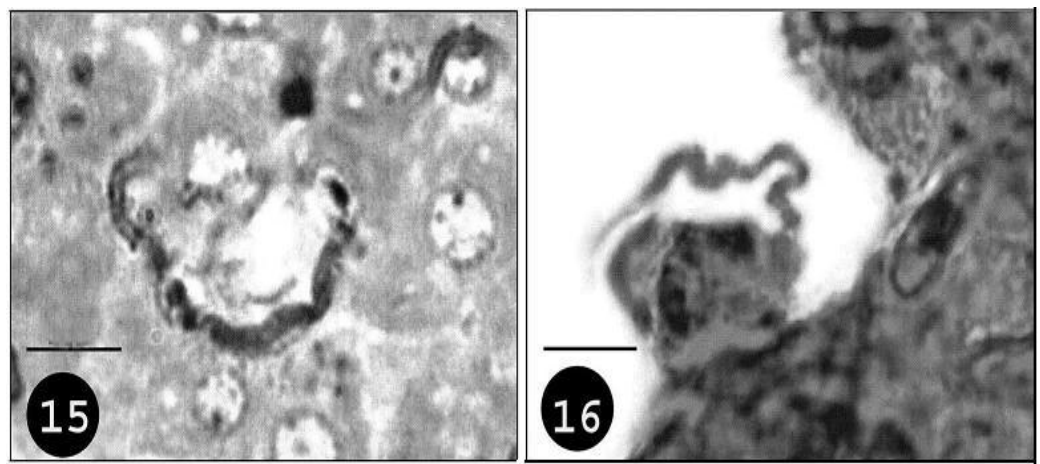

Figs. 15\&16: Photomicrograph of sections from liver of B. bayad fish infected with T. mukasai showed the presence of trypanosomes between liver cells (S. bar $10 \mu \mathrm{m})$.

Using scanning electron membrane, and also showed the positions microscope to investigate the topography of many vacuoles inside the body (Figs. of the blood stage of T. mukasai, showed 17-20). the general shape and the undulating
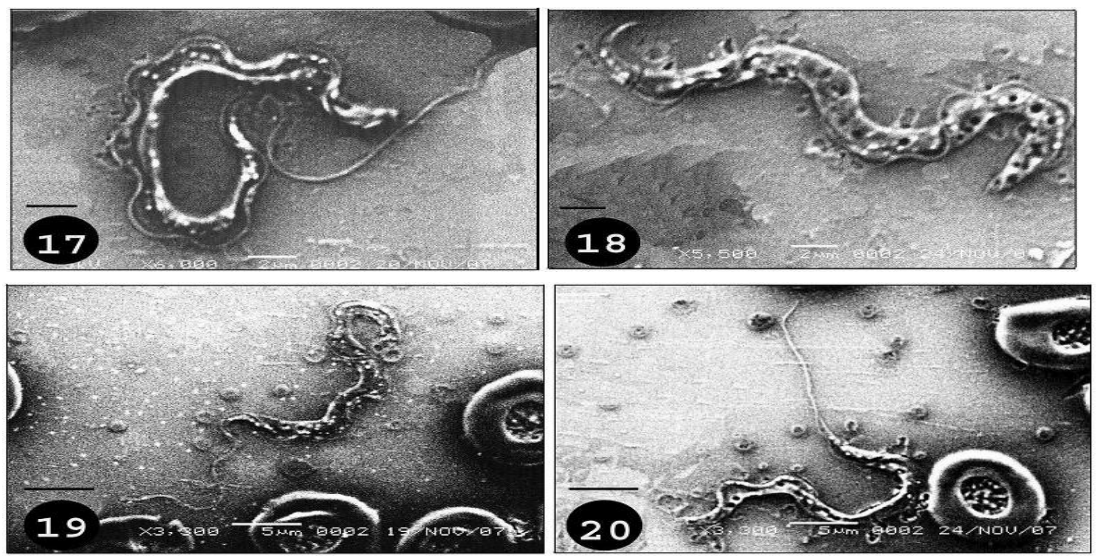

Figs. 17-20: Scanning electron micrographs of T. mukasai in B. bayad fish; Fig. 17. Showed the undulating membrane, length of free flagellum, and the site from which the flagellum arises (S. bar $2 \mu \mathrm{m})$; Fig. 18. Showed vacuoles inside the body, and revealed that the flagellum coils around the body within the undulating membrane (S. bar $2 \mu \mathrm{m}$ ); Fig. 19. Showed free flagellum and the undulating membrane (S. bar $5 \mu \mathrm{m}$ ); Fig. 20. Showed the pointed anterior end of the body in addition to vacuoles and the free flagellum (S. bar $5 \mu \mathrm{m}$ ).

\section{DISCUSSION}

\section{T. mukasai Van As et al. 2004}

Baker, J.R. (1960) recorded T. mukasai in T. esculenta, Or. variabilis, and B. docmac from Lake Victoria. The same author recorded T. tobeyi from $C$. angolensis but suggested that T. tobeyi is synonymous of T. mukasai. Negm-ElDin, M.M. (1998) considered these both trypanosomes species are belong to the same species. He mentioned a certain characters those agreed with the data in the present study as T. mukasai (Table 3).

Pienaar, U.D.V. (1962) reported T. clariense from C. gariepinus fish caught from South Africa. Usually, Pienaar, U.D.V. (1962) reported the same species in his study of blood parasites of South Africa reptiles, total body length (35-48) $\mu \mathrm{m}$ and width (1.3-2.7) $\mu \mathrm{m}$, this parasite falls within the ranges of those from C. gariepinus in the Okavango 
Delta, as well as those of T. mukasai. He also mentioned the difficulty in staining the free flagellum, a characteristic found in the majority of the Okavango specimens. Based on Pienaar, U.D.V. (1962) original description (no type material was deposited, the name $T$. clariense may therefore also prove to be a junior synonym of T. mukasai.

Saoud, M.F.A. (1976) recorded without description, trypanosomes from C. anguilaris and C. lazera in the White Nile in Sudan. Mohammed (1978) described T. alhaussainii from C. lazera caught from the Nile near Cairo, A. R. Egypt. By comparing the measurements of this species with those of T. mukasai and the present species in C. lazera it was found that the three species are similar. Smit, et al. (2004) reported T. mukasai in 9 host fishes: Or. andersonii, Se. angusticeps, Se. macrocephalus, Se. robustus, $C$. gariepinus, $C$. theodorae, $P$. ngamensis, $S$. nigromaculatus, and $S$. vanderwaali.

In the present study $T$. mukasai is recorded from 6 fish species: Or. niloticus, Ti. zilli, L. niloticus, Ch. auratus, C. lazera and B. bayad.

Dutton, et al. (1907) found Trypanosomes in C. angolensis caught at Leopoldville in the Congo. They described three forms of Trypanosomes, small, medium, and large, and all of them were characterized by the possession of a large four-lobed granular kinetoplast, a long oval granular nucleus and spherical longitudinal striations or myonemes. Mohammed, M.A. (1978) described T. alhaussainii from $C$. lazera caught from the Nile near Cairo, A. R. Egypt. In Mohammed's openion T. alhaussaini is certainly distinct from $T$. toddi but shows some similarity to T. andradesilvae from which it can be differentiated by the wider body, longer free flagellum and the position of the nucleus. Marwan, A.M. (1980) described trypanosomes from $C$. lazera at Assiut, A. R. Egypt where only two forms; the large form is almost similar to Mohammed's account of $T$. alhaussaini which was described as a monomorphic trypanosome. Smit, et al. (2004) described T. mukasai from $C$. gariepinus (syn $C$. lazera) from Botswana.

In the present work, only one form of trypanosomes is represented with long cylindrical body measured 44-52.5 $\mu \mathrm{m}$ in length. Nucleus is spherical to oval, situated in the posterior half of the body. And this form is similar to $T$. alhaussaini, 1978 and the large form of trypanosomes of Marwan, A.M. (1980) from the same host and each of them are similar to T. mukasai Smit, et al., 2004 so that the present species is identified as $T$. mukasai.

\section{T. mukasai in B. bayad:}

The earliest record of trypanosomes from $B$. bayad is that of Neave, S. (1906) who reported and figured these parasites in that host caught from the Nile at Sudan. Wenyon, C.M. (1908) also reported trypanosomes in $B$. bayad caught from the Sudanise Nile. Saoud, M.F.A. (1976) reported trypanosomes in B. bayad and B. docmac caught from the White Nile in the Sudan. All these previous authors only reported trypanosomes in Bagrus fishes but no description or specific identification were given. Marwan, A.M. (1980) described trypanosomes from $B$. bayad and $B$. docmac was the first detailed description of trypanosomes from Bugrus fishes, and named it T. bagrii. Trypanosomes from $B$. bayad fish in the present work may be related to trypanosomes described by Marwan, A.M. (1980) from Ch. auratus which belongs to the same family of fish. But T. mansouri described before from Chrysichthys fishes are shorter and broader from those described from $B$. bayad (Table 1). Certain differences can also be seen in the shape and size of kinetoplast where in $T$. mansouri the kinetoplast is large, elongated and extends to the pointed posterior end of the body, but in the present trypanosomes 
from B. bayad, the kinetoplast is rounded to oval in structure, and in some cases there is a distance between it and the posterior end of the body. Trypanosomes described here differ from T. alhaussaini described from C. lazera (Table 1), where T. alhaussaini is broader and longer than Bagrus trypanosomes, and also they differ in the position and shape of nucleus and in the position of kinetoplast. When comparing the present trypanosome with T. bagrii, Marwan, 1980 (Table 1) it was found that the present trypanosome is similar to the second form of T. bagrii (Marwan, A.M., 1980) in both features and measurements and both of them are similar to $T$. mukasai Smit, et al. (2004) and they only differ in the host, so that T. bagrii Marwan, 1980 and the present Trypanosoma in B. bayad might be a synonymous with $T$. mukasai.

\section{T. mukasai in Ch. auratus:}

Mohammed, M.A.

described T. mansouri from Ch. auratus which were caught from River Nile near Cairo. The incidence of trypanosomes in Ch. auratus in Mohammed's work was 60\%. In Marwan study (1980) on Ch. auratus caught from the Nile in Assiute, Upper Egypt, the incidence of trypanosomes was $35.76 \%$.

In the present study on Ch. auratus, the specimens were caught from the Nile in Upper Egypt at Qena, the incidence of trypanosomes is $37.5 \%$. Smit, et al. (2004) described T. mukasai from different fishes (Table 2). Trypanosomes in the present study can be identified as $T$. mukasai, where it differs from $T$. mansouri in being monomorphic and the length and width of the nucleus in the present trypanosome is lesser than $T$. mansouri. Also the kinetoplast is larger and wider than in T. mansouri; while it is similar to $T$. mukasai in being monomorphic and other measurements (Table 1).

\section{T. cyanophilum Mohamed, 1978 in Ch. rueppelli}

It appeared from the above description that the species under consideration can be identified as $T$. cyanophylum Mohammed, 1978. This species was previously described from Ch. rueppelli caught from the River Nile near Cairo, and the incidence of infection was 44.7\%. Marwan, A.M. (1980) reported the same species of $T$. in $C h$. rueppelli also but at Assiut, A. R. Egypt and the incidence of infection was $35.76 \%$.

In the present work, Ch. rueppelli caught from the Nile in Upper Egypt at Qena, where the incidence of infection is $52.9 \%$ (higher than Mohammed's and Marwan incidence), the above description fits fairly well with that of Mohammed, M.A. (1978) and Marwan, A.M. (1980) except in minor morphological details which are summarized in table (1). Previously, trypanosomes were recorded from Chrysichthys fishes from the Nile by Wenyon, C.M. (1909) and Saoud, M.F.A. (1976). Both records are from Sudan but the parasites were neither described nor named by those authors. Mohammed, M.A. (1978) offered a detailed description for T. cyanophilum, and described it as a deep blue staining trypanosome with Giemsa's stain. The only other species with this staining characteristic is T. percae Brumpt, 1906 which was re described few years later by Minchin, E.A. (1909). Apart from differences in the last species which belongs to different sub orders of fishes, $T$. percae is considerably longer and thiner than T. cyanophilum. Mohammed, M.A. (1978) and Marwan, A.M. (1980) reported two forms (small and large) of T. cyanophilum from Ch. rueppelli fishes, but in the present work three forms are described, (small, medium and large) and their measurements are summarized in Table (3). 


\section{T. cataractae Putz, 1972 from Ti. zilli}

According to Lom, J. and Dykova, I. (1992) T. cataractae Putz, 1972 infects four cyprinids- Rhinichthys cataractae, $R$. antatulus, Exoglossum maxillingua and Campostoma anomalum in West Virginia (USA). The body length is $17 \mu \mathrm{m}$ and the body width is $2 \mu \mathrm{m}$ and was described as showing no distinguishing features.

In the present work Trypanosoma species which is observed in Ti. zilli, family Cichlidae, and measures $17-20$ $\mu \mathrm{m}$ in length; and $6.5-8.0 \mu \mathrm{m}$ in width agrees with $T$. cataractae which was described by Putz, R.E. (1972).

Trypanosoma new species parasitising Ch. rueppelli in the present study

Comparing this species with other trypanosomes in freshwater fishes, it was found that it resembles T. striati Qadri, 1955 in shape and size which was 32-54 $\times 2-8 \mu \mathrm{m}$ in the first and $48.5 \times 5.5 \mu \mathrm{m}$ in the present species, the two are similar also in having a distinct nucleus in the anterior half of the body, but the free flagellum in T. striati Qadri, 1955 was 8 $-11 \mu \mathrm{m}$; while in the present species it is not distincted. In addition that $T$. sriati Qadri, 1955 was observed in Oph. striatus from India, but the present species is observed in Ch. rueppelli in
Qena, Egypt (a new locality). It resembles T. immanis Froes, et al., 1978 which was found in $L$. anus from Rio Grande do Sul, Brazil in size and in the site of nucleus, and in the distance between the kinetoplast and the posterior end of the body, but they differ in the body length, where the present species is $48.5 \mu \mathrm{m}$ in length but the previous one was $105-132 \mu \mathrm{m}$. Also the free flagellum in the previous species was 6-7 $\mu \mathrm{m}$ while in the present species it is not distinct. Also this species resembles the adult stage of T. gargantua Laird, 1951 which was recorded from Raja nosuta from New Zealand in body width which was 4.6-13.7 $\mu \mathrm{m}$ in the previous trypanosomes and $5.5 \mu \mathrm{m}$ in the present species. Also the two are without a free flagellum and posses a distinct nucleus which lies in the anterior half of the body. But they differ in body length where it was 66.7-131 $\mu \mathrm{m}$ in $T$. gargantua and $48.5 \mu \mathrm{m}$ in the present species.

From the previous comparison, the present species differs from the previous trypanosomes in some respects, so that the present trypanosome could be identified as a new trypanosome species called $T$. rueppelli according to its host (Ch. rueppelli).

Table 1: Dimensions by $\mu \mathrm{m}$ of some previously described Trypanosoma spp. In fresh water fishes in Egypt (KL Kinetoplast length; $K W$ Kinetoplast width; $K N$ Distance between the posterior end of nucleus and the anterior end of kinetoplast; $N L$ Nucleus length; NW Nucleus width; NA Distance between the anterior end of nucleus and the anterior nucleus and the anterior tip of the body; FF Free flagellum; BL Body length without flagellum; $T L$ Total body length with flagellum; $B W$ Body width).

\begin{tabular}{|c|c|c|c|c|c|c|c|}
\hline \multirow{2}{*}{} & \multicolumn{3}{|c|}{ Trypanosoma mansouri Mohammed, } & \multicolumn{2}{c|}{$\begin{array}{c}\text { Trypanosoma alhaussainii } \\
\text { Mohammed, 1978 }\end{array}$} & \multicolumn{2}{c|}{$\begin{array}{c}\text { Trypanosoma bagrii } \\
\text { Marwan, 1980 }\end{array}$} \\
\cline { 2 - 8 } & \multicolumn{3}{|c}{ Chrysichthys auratus } & \multicolumn{2}{c|}{ Clarias lazera } & \multicolumn{3}{c|}{ Bagrus bayad } \\
\cline { 2 - 8 } & Form I & Form II & Form III & Small form & Large form & Form I & Form II \\
\hline KL & $0.5-1.0$ & $0.7-1.1$ & $0.85-1.3$ & $1.0-1.6$ & $0.7-1.2$ & $0.5-0.8$ & $0.4-0.65$ \\
KW & $0.5-0.7$ & $0.7-0.9$ & $0.77-0.5$ & $0.3-0.6$ & $0.7-1.5$ & $0.5-0.7$ & $0.4-0.7$ \\
KN & $15.5-19$ & $15.9-18.4$ & $14.9-10.5$ & $14-18$ & $12.2-15.6$ & $12.4-19.2$ & $10.5-19$ \\
NL & $2.5-4.0$ & $3.5-5.0$ & $2.2-3.9$ & $3.5-5.0$ & $2.5-3.0$ & $3.0-4.5$ & $1.0-3.0$ \\
NW & $1.5-3.0$ & $2.5-3.0$ & $1.04-2.5$ & $1.6-3.3$ & $1-2$ & $1.0-1.5$ & $0.5-1.25$ \\
NA & $15.7-20$ & $16.2-19$ & $7.9-11.6$ & $14-18$ & $6.6-7.1$ & $9.25-13.2$ & $12.5-15.5$ \\
FF & $4.5-11$ & $10-11.5$ & $13.5-7.0$ & $6.5-12$ & $8.5-12.5$ & $7.9-15.5$ & 0.0 \\
BL & $31.5-42.5$ & $33.5-37$ & $19-26.5$ & $35-37.5$ & $24-25.5$ & $31.5-34$ & $28-36$ \\
TL & $34.4-47$ & $43.5-48.5$ & $29-35.7$ & $41-55$ & $32.5-37$ & $39-49.5$ & $28-36$ \\
BW & $2.5-3.2$ & $3.5-4.0$ & $1.06-2.8$ & $2.5-3.5$ & $2.0-3.0$ & $1.5-3.0$ & $1.5-2.5$ \\
\hline
\end{tabular}


Table 2: Trypanosoma mukasai Smit et al., 2004 from Botswana (TL Total length with flagellum; BL Body length without flagellum; $B W$ Body width; NA Distance between middle of nucleus and anterior body end; NL Nucleus length; $P N$ Distance between middle of nucleus and posterior body end; $P K$ Distance between middle of kinetoplast and posterior body end; $K N$ Distance between middle of kinetoplast and the middle of nucleus; NI Nuclear index = PN / NA).

\begin{tabular}{|c|c|c|c|c|c|c|c|c|c|}
\hline & TL & BL & BW & NA & NL & PN & PK & $\mathbf{K N}$ & NI \\
\hline $\begin{array}{l}\text { Oreochromis } \\
\text { andersonii }\end{array}$ & $45.2-63.3$ & $37.7-53.6$ & $3.9-5.6$ & $\begin{array}{l}17.3- \\
27.3\end{array}$ & $2.9-3.7$ & $19.3-28.2$ & $\begin{array}{l}1.1- \\
1.8\end{array}$ & $17.9-26.4$ & 1.1 \\
\hline $\begin{array}{l}\text { Serranochromis } \\
\text { angusticeps }\end{array}$ & $51.6-57.1$ & $43.9-48.2$ & $3.2-6.2$ & $\begin{array}{l}17.3- \\
24.8\end{array}$ & $3.6-4.6$ & $23.6-29.1$ & $\begin{array}{l}1.6- \\
2.9\end{array}$ & $19.4-26.8$ & 1.2 \\
\hline $\begin{array}{l}\text { Serranochromis } \\
\text { macrocephalu }\end{array}$ & $51.5-61.6$ & $44.6-50.8$ & $3.9-6.1$ & $\begin{array}{l}19.1- \\
23.6\end{array}$ & $3.9-5.0$ & $25.5-27.2$ & $\begin{array}{c}2.5- \\
3.2\end{array}$ & $22.3-24.7$ & 1.2 \\
\hline $\begin{array}{l}\text { Serranochromis } \\
\text { robustus }\end{array}$ & $29.5-70.1$ & $23.6-60.9$ & $1.4-5.7$ & $\begin{array}{l}8.2- \\
27.3\end{array}$ & $5.8-2.6$ & $15.5-33.6$ & $\begin{array}{l}0.9- \\
2.2\end{array}$ & $14.5-31.5$ & 1.2 \\
\hline $\begin{array}{l}\text { Clarias } \\
\text { gariepinus }\end{array}$ & $30.1-52.4$ & $21.7-41.5$ & $1.2-3.6$ & $\begin{array}{l}8.6- \\
22.1\end{array}$ & $1.9-4.1$ & $13.1-22.2$ & $\begin{array}{c}0.8- \\
1.7\end{array}$ & $12.2-20.5$ & 1.2 \\
\hline $\begin{array}{l}\text { Clarias } \\
\text { theodorae }\end{array}$ & $32.7-62.5$ & $22.7-54.9$ & $1.8-3.5$ & $\begin{array}{l}10.9- \\
26.9\end{array}$ & $3.2-5.5$ & $30.4-11.8$ & $\begin{array}{l}1.4- \\
2.1\end{array}$ & $28.4-10.5$ & 1.1 \\
\hline $\begin{array}{l}\text { Parauchenogla } \\
\text { nis ngamensis }\end{array}$ & $33.1-80.8$ & $30.8-75.4$ & $\begin{array}{l}2.3- \\
11.5\end{array}$ & $11-40$ & $3.2-5.0$ & $40-15$ & $\begin{array}{l}1.5- \\
6.2\end{array}$ & $13.4-33.8$ & 1.2 \\
\hline $\begin{array}{l}\text { Synodontis } \\
\text { nigromaculatus }\end{array}$ & $36.6-54.0$ & $28-43.6$ & $2.0-4.0$ & $\begin{array}{l}10.3- \\
20.2\end{array}$ & $2.7-4.6$ & $27.3-17.7$ & $\begin{array}{l}1.1- \\
2.2\end{array}$ & $16.2-25.8$ & 1.4 \\
\hline $\begin{array}{l}\text { Synodontis } \\
\text { vanderwaali }\end{array}$ & $32-48$ & $26.7-40.9$ & $1.1-3.0$ & $10-18.6$ & $2.2-3.7$ & $23.3-14.6$ & $\begin{array}{c}0.9- \\
1.4\end{array}$ & $13.6-22.1$ & 1.3 \\
\hline $\begin{array}{l}\text { Schilbe } \\
\text { intermedius }\end{array}$ & $35.3-51.6$ & $31.6-42.5$ & $2.5-4.7$ & $\begin{array}{l}19.5- \\
13.1\end{array}$ & $2.6-4.4$ & $18-26.7$ & $\begin{array}{l}1.3- \\
2.1\end{array}$ & $16-25.2$ & 1.4 \\
\hline
\end{tabular}

Table 3: Measurements (in $\mu \mathrm{m}$ ) of trypanosomes in the present study ( $T L$ Total body length with flagellum; $B L$ Body length without flagellum; $B W$ Body width; FF Free flagellum; $N L$ nucleus length; $N W$ Nucleus width; KN Distance between middle of nucleus and kinetoplat; $P K$ - Distance between middle of kinetoplast and posterior body end; $P N$ Distance between middle of nucleus and posterior body end; NA Distance between middle of nucleus and anterior body end).

\begin{tabular}{|c|c|c|c|c|c|c|c|c|c|c|}
\hline & \multicolumn{6}{|c|}{ 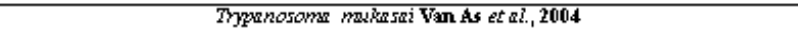 } & \multicolumn{3}{|c|}{ Thponosomn gynophidm Mohamumed, 1978} & \multirow{2}{*}{ 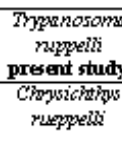 } \\
\hline & olorar iara & $\begin{array}{c}\text { Oreociso } \\
\text { mis } \\
\text { rilatios }\end{array}$ & Milquagib & Lobo vilaticun & $\begin{array}{l}\text { Chpolith } \\
\text { p arotus }\end{array}$ & Bagrus bquag & Fomm I & Form II & Fön III & \\
\hline TL & $47.5-52.5$ & ..... & ...- & $56-61$ & $45-49.5$ & 45.3589 & $31-35.7$ & .... & 45.5 & ..... \\
\hline $\mathbf{B L}$ & $38.5-41$ & $41-43.5$ & $40.2-42.5$ & $50-53$ & $34.5-35.7$ & $32.1-40.7$ & $24-26.7$ & 37.0 & 34 & 48.5 \\
\hline BW & $2.0-2.5$ & $1.8-2.5$ & $2.0-3.2$ & $4.0-4.2$ & $1.2-2.5$ & $1.4-2.2$ & 3.23 .5 & 4.5 & 0.8 & 5.5 \\
\hline FF & $9.0-11.5$ & $\ldots .$. & $\ldots$ & $6.0-7.5$ & $11-14$ & $16.5-17.2$ & $70-9.0$ & $\ldots$ & 11.5 & $\ldots$ \\
\hline FL & $3.0-4.0$ & 2.7 .3 .2 & $3.5-4.0$ & $3.0-4.0$ & $1.4-1.8$ & $3.0-4.4$ & $2.8-3.2$ & 4.8 & 6.5 & 38 \\
\hline NW & $2.1-2.7$ & $1.5-1.8$ & $1.1 \cdot 1.8$ & $4.0-4.3$ & $0.7-1.2$ & $1.0-2.1$ & 3.1 .3 .5 & 4.5 & 5.6 & 4.5 \\
\hline FWT & $20-22$ & $20.5-23$ & $22-23$ & $23-25$ & $14-15.5$ & $15.5-17.2$ & $11.2-12.7$ & 19.5 & 20.2 & 26.4 \\
\hline PK & 1.72 .2 & $1.0-1.4$ & $0.7-1.3$ & $0.8-1.0$ & $1.5-2.7$ & $0.9-1.5$ & 0.70 .9 & 0.8 & 1.5 & 3.2 \\
\hline $\mathbf{P N}$ & $23-24$ & $21.5-24$ & $22.5-24$ & $27.5-29$ & $18-19.5$ & $15.5-19.7$ & $14.7-15.5$ & 21 & 21.7 & 30 \\
\hline HA & $15.5-17$ & $17-21$ & $17.5-19.5$ & $24-25.7$ & $15.5-16.5$ & $12-14.6$ & $9.5-11.2$ & 17 & 12.3 & 18.5 \\
\hline $\mathbf{K L}$ & $1.0-1.8$ & $0.7-0.9$ & $0.7-1.3$ & $1.0-1.2$ & $2.0-3.5$ & $0.56-0.71$ & $1.3-1.8$ & 1.2 & 1.1 & 1.0 \\
\hline $\mathbf{K W}$ & $0.5-1.0$ & 0.709 & $0.7-0.9$ & $0.5-0.7$ & $1.5-2.3$ & $0.5-0.6$ & $0.5-0.7$ & 0.9 & 0.8 & 0.7 \\
\hline NI & $1.3-1.5$ & $1.0-1.4$ & $1.1-1.3$ & $1.0-1.2$ & $1.0-1.25$ & $1.0-1.6$ & $1.3-1.63$ & 1.2 & 1.7 & 1.6 \\
\hline
\end{tabular}

\section{REFERENCES}

Akmirza, A. and Tepecik, R.E. (2007). Seasonal variation in some haematological parameters in naturally infected and uninfected roach (Rutilus rutilus) with Cryptobia tincae. Journal of Applied Biological Sciences, 1 (3): 61-65.

Al-Jafry, A.R. and Rahema, Z.I.F. (1982). Trypanosoma mystuii sp. n. from a fresh water Teleost fish Mystus pelusius solander, in Iraq. Journal of Biological Science, 13(1): 3-10.

Al-Jafry, A.R., Ali, N.M. and Salih, N.E. (1988). Trypanosoma garrae n.sp. from the fresh water fish Garra rufa (Family: Cyprinidae). Journal of Biological Science Research, Baghdad, 19 (3): 735-738.

Al-Salim, N.K. (1980). Studies on some diseases of fish. Ph.D. thesis University College, Swansea.

Al-Salim, N.K. (1985). Trypanosoma Carasobarbi sp. n. from a fresh water fish, Carasobarbus luteus (Hechel), 1843, (Family: Cyprinidae) from Shatt Al-Arab River, Basrah, Iraq. Journal of Biological Science, 162:205-215. 
Al-Salim, N.K. and Al-Daraji, A.M.S. (1990). Trypanosoma arabica sp. N. from the freshwater fish Silurus triostegus Heckel in Iraq. Acta ichthyologica Et Piscatoria, 20: 8589.

Al-Salim, N.K. and Al-Daraji, A.M.S. (1992). Trypanosoma basrensis $\mathrm{n}$. sp. from the freshwater fish, Aspius vorax Heckel. 1843 in Iraq. Basrah Journal of Agricultural Science, 5: 151-155

Baker, J.R. (1960). Trypanosomes and dactylosomes from the blood of fresh water fish in East Africa. Parasitology, 50: 515-526.

Baker, J.R. (1961). Trypanosomes of African fresh water fish: an addendum. Parasitology,51: 263.

Bouet, G. (1909). Sur quelques trypanosomes des vertébrés à sang froid de l'Afrique Occidentale Française. Comptes Rendus des Seances de la Société de Biologie et de ses Filiales, 66: 609.

Daly, J.J. and Degiusti, D.L. (1971). Trypanosoma catostomi n. sp. from the white sucker, Catostomus commersoni (lacepede). J. of Protozoology, 18: 414 - 417.

Dias, J.A.T.S. (1952). Uma nova especie di tripanosoma, parasita do Clarias gariepinus (Burchell, 1822), peixe africano de agua doce. Annales do Instituto de Medicina Tropica, 1 9: 167-179.

Duijn, C.V. (1973). Diseases of fishes, Ist edn, Lliffe Books, London.

Dutton, J.E., Tood, J.L. and Tobey, E.N. (1907). Concerning certain parasitic protozoa observed in Africa. Part II. Annals of Tropical Medicine and Parasitology, I: 287.

Fantham, H.B. (1919). Some parasitic Protozoa found in South Africa, VI. South African Journal of Sciences, 20: 493-500.

Fattohy, Z.L. (1978). Trypanosoma neinavana sp.n. from fish Barbus grypus, Hackel in Iraq. Current Science India, 47: 33-35.

Froes, D.M., Fortes, E., Lima, D.F. and Leite, V.R.V. (1978). Tres especies novas de trypanosomes de Peixes de agua doce do Brasil (Protozoa,
Kinetoplastida). Revista Brasileira De Biologia, 38: 461 - 468.

Hassan, R. and Qasim, S.Z. (1962). Trypanosoma punctati n. sp. from the fish Ophicephalus puctatus Bloch; common fresh water murrel of India. Zeitschrift Fuer Parasitenkunde, 22: $118-122$.

Hassan, A.A., Akinsanya, B. and Adegbaju, W. A. (2007). Haemoparasites of Clarias Gariepinus and Synodontis clarias from Lekki Lagoon, Lagos Nigeria. Journal of American science, 3(3): 61- 67.

Hawking, F. (1957). Trypanosomes of English fresh water fish. Transactions of the Royal Society of Tropical Medicine and Hygiene, 51: $375-376$.

Hoare, C.A. (1932). On protozoal blood parasites collected in Uganda. Parasitology, 24: 210-224.

Hoffman, G.L. (1970). Parasites of North American Freshwater fishes .University Calf. Press, Berkely.

Keysselitz, G. (1906). Generations, and wirtswechsel von Trypanosoma borelli Laveran et Mesnil. Archiv Fuer Protistenkunde, 7:1-74.

Laveran, A. and Mesnil, F.(1901). Deux hemogreines nouvelles des poisons. Comptes Rendus De Lacademie Des Sciences Serie II, 133: 572 - 577.

Lom, J. (1979). Biology of the trypanosomes and trypanoplasms of fish in Lumsden WHR, Evans DA (eds) Biology of the kinetoplastida. Academic press, New York 11: 269 $-337$.

Lom, J. and Dykova, I. (1992). Protozoan parasites of fishes. Development in Aquaculture and Fisheries Science, 26: 1-315.

Mandal, A.K. (1977). Trypanosoma choudhuryi sp. Nov. from Tilapia mossambica (peters). Acta Protozoology, 16:1-4.

Mantel, R. (1905). Trypanosome d'un poisson de Cochinchine. Comptes Rendus des Séances et Mémoires de la Société de Biologie, 58: 1016.

Marwan, A.M. (1980). Studies on the blood and kidney parasites in Assiut Governorate, A.R. Egypt. M.sc 
thesis, Assiut University, Assiut, Egypt.

Minchin, E.A. (1909). Observations on the flagellates parasitic in the blood of fresh water fishes. Proceedings of Zoological Society London, 1: 2- 24.

Mohammed, M.A. (1978). Studies on certain protozoan and trematode parasites of some Nile fishes. M. Sc. ThesisFaculty of Science University of Ain Shams Egypt.

Neave, S. (1906). Report of traveling pathologist and naturalist, In: Second report of the Welcome Tropical Research Laboratories, Khartoum, pp. $183-204$.

Negm-El-Din, M. M. (1997). Trypanosoma mukasai (Hoare, 1932) in its biological vector Batracobdelloides tricarinata (Blanchard, 1897) and their life cycles. Deutsche Tierarztliche Wochenscrift, 104: 215-219.

Negm- El-Din, M.M. (1998). Further studies on Trypanosoma mukasai Hoare, 1932 and its biological vector Batracobdelloides tricarinata (Blanchard, 1897). Deutsche Tierarztliche Wochenscrift, 105: 175-181.

Overath, P., Haag, J., Mameza, M.G. and Lischke, A. (1999). Freshwater fish trypansomes: defenation of two types, host control by antibodies and lack of antigenic variation. Parasitology, 119: 591-601

Paperna, I. (1996). Parasites, infections and diseases of fish in Africa-An update, CIFA Tech. Paper, 31, FAO, Rome, Italy. pp $201-220$.

Pienaar, U.D.V. (1962). Haematology of Some South African Reptiles. Witwatersrand University Press, Johannesburg. P 299

Putz, R.E. (1972). Biological studies on the haemoflagellates Cryptobia caractae and Cryptobia salmositica. Technical Papers of the Bureau Sport Fisheries and wildlife, 63: 3-25.

Qadri, S.S. (1955). The morphology of Trypanosome striate n. sp., from an Indian fresh water fish. Parasitology, 45: $79-85$.
Qadri, S.S. (1962). On three new trypanosomes from fresh water fish. Parasitolology, 52:221- 228.

Saoud, M.F.A. (1976). A general survey of the protozoan blood parasites of some Nile fishes from the Sudan. Revue de zoologie africaine, 90 (2): $313-322$.

Smit, N.J., Davies, A.J. and Van As, J.G. 2000. A trypanosome from the silver catfish (Schilbe intermedius) in the Okavango Delta, Botswana. Bulletin of the European Association of Fish Pathology, 20: $116-119$.

Smit, N.J., Van As, J.G. and Davies, A.J. 2004. Fish trypanosomes from the Okavango Delta, Botswana. Folia Parasitologica, 51:299-303.

Warsi, A.A. and Fattohy, A.L. 1976. Trypanosoma acanthobramae n. sp. from a fresh water fish, Acanthobrama marmid, Heckel (Family: cyprinidae) from the River Tigris, Iraq. Current Science India, 45(23): 838-839.

Wenyon, C.M. 1908. Report of travelling parasitologist and protozoologist. Report of the Wellcome Tropical Research. Laboratories. Khartoum, 3: $121-168$.

Wenyon, C.M. 1909. Report of traveling pathologist and protozologist. 3rd Report of the Wellcome Tropical Research. Laboratories. Khartoum, $p$ $120-168$

Woo, P.T.K. 1987. Cryptobia and cryptobiosis in fishes. Advances in Parasitology, 26:199 - 237.

Woo, P.T.K. 1987. Immune response of fish to parasitic protozoa. Parasitology Today, 3:186 - 188.

Woo, P.T.K. 1994. Flagellate parasites of fish. In: Krier JP (ed) parasitic protozoa. Academic press, New York, 8: 1-80.

Zintl, A., Poole, W.R., Voorheis, H.P. and Holland, C.V. 1997. Naturally occurring Trypanosoma granulosum infections in the European eel, Anguilla anguilla L. from County Mayo, western Ireland. Journal of Fish Diseases, 20: 333-341. 
Abbreviation used in this article

\begin{tabular}{|c|c|}
\hline Name & Abbreviation \\
\hline 01- Trypanosoma ------- & T. ------- \\
02- Bagrus bayad & B. bayed \\
03- Chrysichthys rueppelli & Ch. Rueppelli \\
04- Chrysichthys Auratus & Ch. Auratus \\
05- Tilapia zilli & Ti. zilli \\
06- Oreochromis niloticus & Or. niloticus \\
07- Clarias lazera & C. lazera \\
08- Labeo niloticus & L. niloticus \\
09- Synodontis schall & S schall \\
10- Synodontis clarias & S clarias \\
11- Schilbe intermedius & Sc. Intermedius \\
12- Ophicephalus obsccurus & Oph. Obsccurus \\
13- Serranochromis robustus & Se. robustus \\
\hline
\end{tabular}

\section{ARABIC SUMMARY}

\section{دراسات باستخدام المجهر الضوئى والمجهر الأكترونى الماسح للتريبانوسوما (Trypanosoma)

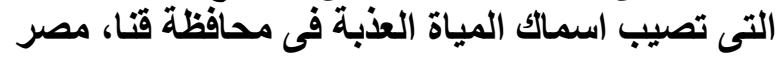

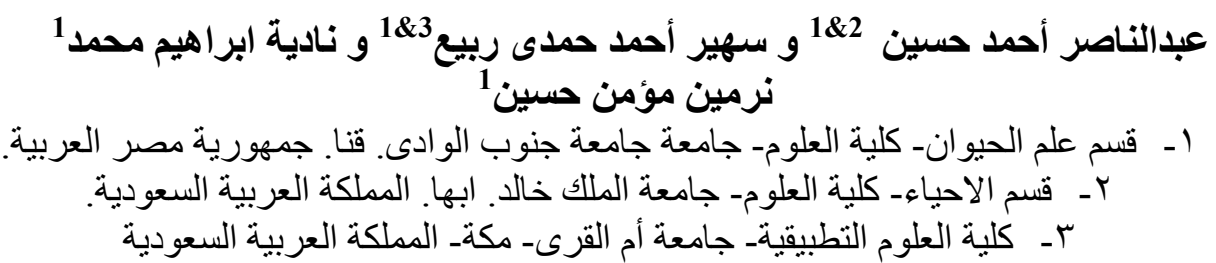

تم أخذ عينات اسماك المياه العذبة من مناطق مختلفة لنهر النيل في محافظـة قنا (قوص، قفط، دندر الفا،

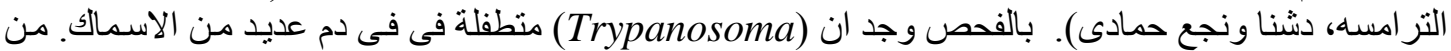

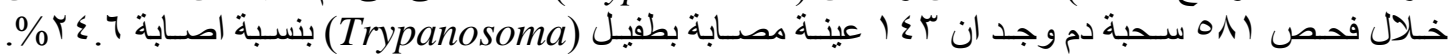

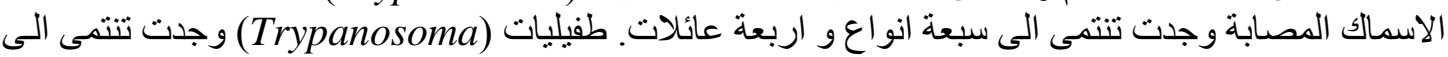

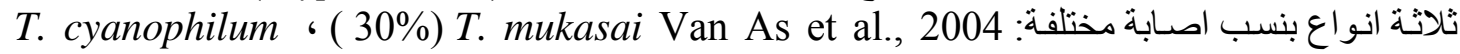

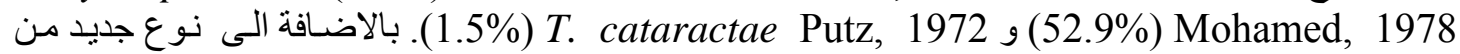

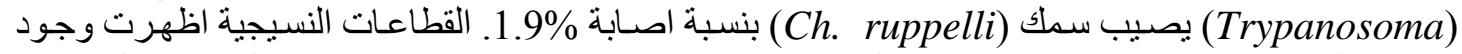
اطوار بالغة من Tukasai . Tين خلايـا الكبد. ايضـا تم فحص Tukasai . باستخدام المجهر الالكترونى 